\title{
Does diabetes blight work productivity: A cross-sectional investigation on selected Type 2 diabetes participants
}

Sivapriya Thiyagarajan, Sheila John

Department of Home Science, Women's Christian College, Chennai, Tamil Nadu, India

\section{A B S T R A C T}

Background: Diabetes is one of the leading global health predicaments of the 2 Ist century. Due to rapid urbanization and lifestyle changes, more and more people become victim to diabetes every year. Many countries spend a chunk of their total health expenditure on diabetes. Thus, the disease is a major challenge for individuals, their families, and the healthcare system. It has become a hurdle to sustainable economic development as it cripples productivity. Methodology: With this background, the daily routine, work place productivity, and accomplishment of goals, both short- and long-term, were assessed for 200 diabetic subjects using a diabetes productivity measure. Results: Since Type 2 diabetes subjects with I-3 years of disease duration and without any comorbid conditions were selected for this study, $44 \%$ indicated that diabetes slightly had an impact on their long-term goal whereas $2 \%$ identified that diabetes was a burden and it prohibited them from achieving their long-term goals. Conclusion: Massive education and awareness programs are crucial to improve the diagnosis and management of all types of diabetes and to embed lifestyle changes that will slow the rise in Type 2 diabetes.

Key words: Diabetes productivity measure, goals, productivity, work place

\section{INTRODUCTION}

Diabetes is termed as "pandemic" in the $21^{\text {st }}$ century due to escalating incidence across all countries, and it has been accorded the status of "public health priority" in most of the nations. ${ }^{[1]}$ Diabetes levies a huge monetary burden on individuals and families, national health systems, and countries. Health spending on diabetes accounted for $10.8 \%$ of total health expenditure worldwide in 2013. Health expenditure includes medical spending on diabetes by health systems, as well as by people living with diabetes and their families. ${ }^{[2]}$

\begin{tabular}{|l|l|}
\hline \multicolumn{2}{|c|}{ Access this article online } \\
\hline Quick Response Code: & Website: \\
\hline & www.joshd.net \\
\hline & \\
\hline
\end{tabular}

In case of Type 1 diabetes, many children and adolescents find it challenging to deal with their disease emotionally. Diabetes can result in discrimination and may limit social relationships. ${ }^{[3]}$ Researches have established deleterious associations between diabetes and employment outcomes. It can shake employment in a number of ways. First, diabetes complications may preclude working entirely or enhance absenteeism for those who work. Second, efficiency while at work may also be impaired. Third, individuals with diabetes may face employment discrimination. ${ }^{[4]}$ This

This is an open access article distributed under the terms of the
Creative Commons Attribution-NonCommercial-ShareAlike 3.0
License, which allows others to remix, tweak, and build upon the
work non-commercially, as long as the author is credited and the
new creations are licensed under the identical terms.

For reprints contact: reprints@medknow.com

How to cite this article: Thiyagarajan S, John S. Does diabetes blight work productivity: A cross-sectional investigation on selected Type 2 diabetes participants. J Soc Health Diabetes 2017;5:43-6.

Corresponding Author: Sivapriya Thiyagarajan, Department of Home Science, Women's Christian College, Chennai, Tamil Nadu, India. E-mail: sivaamanick@gmail.com 
debilitating disorder has a profound negative effect on economic productivity due to early retirement, increased sick days, disability, and mortality. ${ }^{[5]}$

The world is facing an unprecedented and sustained increase in the prevalence of diabetes. While there are a number of aspects that influence the development of Type 2 diabetes, it is obvious that the most influential are lifestyle behaviors which include consumption of processed foods, physical inactivity, and long sedentary periods. In sync, these behaviors are associated with an increased risk of being overweight or obese and the development of Type 2 diabetes. ${ }^{[6]}$

Thus, the purpose of this study was to conduct a cross-sectional survey on selected diabetic subjects to assess the impact of Type 2 diabetes mellitus on individuals' productivity in work place as well as their everyday chores.

\section{MAterials ANd Methods}

This study protocol was reviewed and approved by the Independent Institutional Ethical Committee. A cross-sectional study was conducted randomly among 200 diabetes subjects attending an outpatient diabetic clinic. Individuals were approached during their consultation and asked whether they would like to participate in a questionnaire study. All participants provided written informed consent. The inclusion criteria were diabetic subjects within the age of 40-60 years, without any other complication, and the duration of disease to be within 1-3 years. A 14-item questionnaire, developed by Brod et al., 2006, was used to obtain information from the patients after getting permission from Mapi Research Trust.

\section{RESULTS AND DISCUSSION}

The demographic profile of the selected subjects such as age, gender, education, and occupational status is presented in Table 1. Among the selected 200 subjects, majority of $41 \%$ were below the age group of $55-60$ years followed by $22 \%$ in the age group of $45-49$ years. Only 2\% of the participants were in the age group of 35-39 years. When the distribution of gender was interpreted, 69\% were male and $31 \%$ were female. Major percent (48.5\%) of the subjects had finished their secondary education while $23.5 \%$ were illiterates. A minority percent of 2 had professional degrees and $8.5 \%$ were holding graduate degrees. When occupation pattern of the subject was studied, 27\% were unskilled workers and 19\% were skilled workers. About $8.5 \%$ were business men and $7 \%$ were professionals. Homemakers represented $28 \%$ and retired officers were about $10.5 \%$ of the selected subjects.
Diabetes productivity measure

Impact of diabetes on everyday chores [Table 2]

When the subjects were queried whether their disease condition precluded from completing matters that are of much vital, $73 \%$ reported that diabetes did not prevent them from completing important things while $16 \%$ voiced that sometimes the disease disabled them from doing important things. A greater part of $53 \%$ of the subjects spoke that diabetes sometimes prevented them from concentrating on needs while $36 \%$ were confident that they were able to focus on their daily needs without any

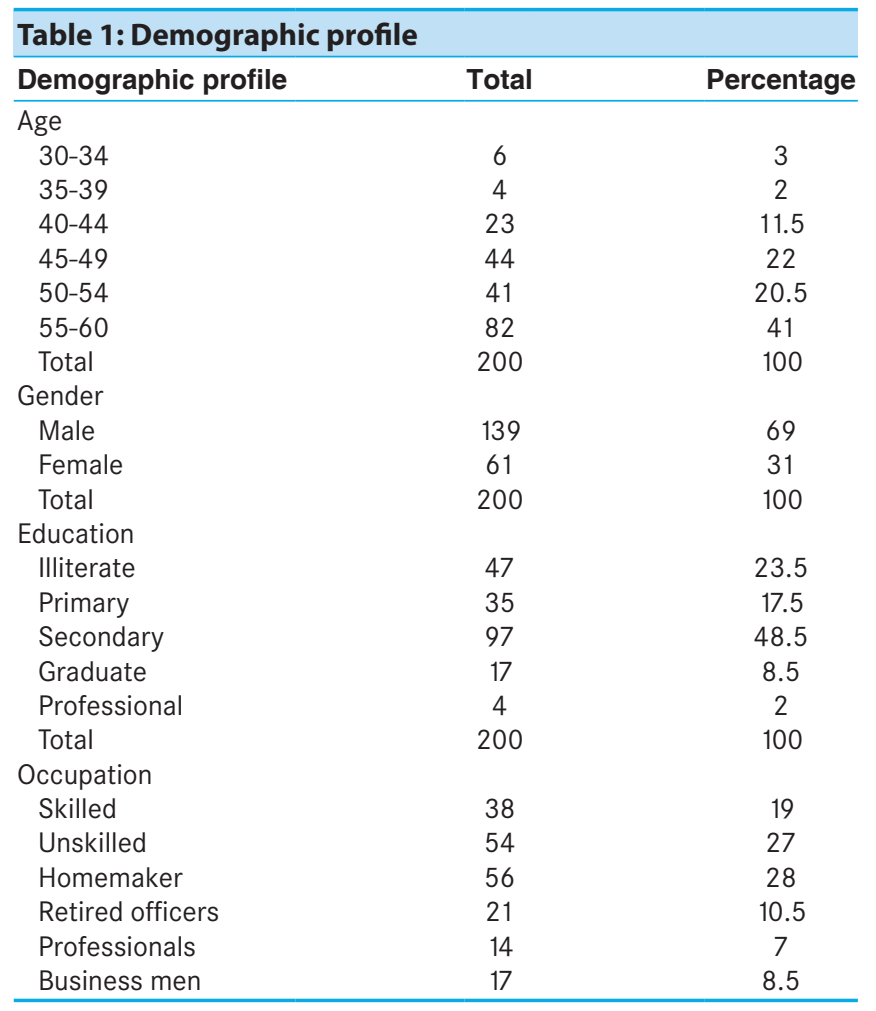

Table 2: Impact of diabetes on everyday chores

\begin{tabular}{|c|c|c|c|c|}
\hline $\begin{array}{l}\text { Impact of diabetes } \\
\text { on everyday chores }\end{array}$ & Never & Rarely & Sometimes & Often \\
\hline $\begin{array}{l}\text { Prevents from completing } \\
\text { matters that are important }\end{array}$ & 73 & 8 & 16 & 3 \\
\hline $\begin{array}{l}\text { Prevents from concentrating } \\
\text { on needs }\end{array}$ & 36 & 7 & 53 & 4 \\
\hline $\begin{array}{l}\text { Interfere with ability to } \\
\text { finish daily errands }\end{array}$ & 45 & 11 & 34 & 10 \\
\hline $\begin{array}{l}\text { Take longer than essential } \\
\text { to complete chores }\end{array}$ & 4 & 66 & 27 & 3 \\
\hline $\begin{array}{l}\text { Trouble in getting up and } \\
\text { being active in the morning }\end{array}$ & 9 & 34 & 45 & 12 \\
\hline Limits daily activities & 11 & 41 & 37 & 11 \\
\hline Achieve less than aimed & 7 & 45 & 40 & 8 \\
\hline $\begin{array}{l}\text { Too exhausted to } \\
\text { accomplish target }\end{array}$ & 7 & 47 & 39 & 7 \\
\hline $\begin{array}{l}\text { Symptoms of low blood } \\
\text { sugar hinders ability to } \\
\text { perform }\end{array}$ & 4 & 38 & 48 & 10 \\
\hline
\end{tabular}


difficulty. About $45 \%$ of the subjects sometimes had trouble in getting up and being active in the morning and $34 \%$ rarely had distress in getting up and being active.

About $41 \%$ were assured that their ailment was not an obstacle for achieving while $11 \%$ grieved that diabetes amputates them from achieving their goal. Symptoms of diabetes such as giddiness, head ache, and palpitations had sometimes hindered $48 \%$ of the subjects while $38 \%$ were satiated that rarely hypoglycemic symptoms slowed down their performances.

The reports of our study subjects were in consonance with Satman et al., 2012. Overall impairment of daily activities was reported as $29.2 \%$. Patients with metabolic complications and cardiovascular complications had reported more impairment. ${ }^{[7]}$

Impact of diabetes in work place [Table 3]

A majority of $66 \%$ stated that they had no exertion in performing their duties while $30 \%$ indicated that sometimes they lost their temper with co-workers. About $46 \%$ of the subjects expressed that they were rarely absent from work. Procrastination of meetings and project submissions were reported as rarely by a major part of $55 \%$ of subjects. Type 2 diabetes was not associated with more frequent absences. Very few reported working extra hours to make up for reduced productivity. ${ }^{[8]}$ Among working-age individuals with diabetes, work disability was found to be $17 \%$ while among those with a comorbid chronic disease, the disability was significantly higher. ${ }^{[9]}$ The degree of the consequence of diabetes on employment varies with duration of diabetes and the comorbidity conditions.

Impact of diabetes on reaching short-term and long-term goals [Table 4]

Out of the selected subjects, $50 \%$ were contented that diabetes never stopped them from achieving short-term goals, while $45 \%$ informed that diabetes slightly had an influence in achieving short-term goals. When the impact of diabetes on achieving long-term goal was enquired, 24\% stated that their long-term goals were not at all affected by diabetes, $44 \%$ indicated that diabetes slightly had a toll on their long-term goal, and $2 \%$ identified that diabetes was a burden and it prohibited them from achieving their long-term goals.

Since the duration of disease among the selected participants were 1-3 years and they do not have any other complications, diabetes had a sparse impact on their productivity both at home and at work. Impairment of daily routines, work productivity, and long- and short-term goals are influenced by the presence of

\begin{tabular}{|c|c|c|c|c|}
\hline $\begin{array}{l}\text { Impact of diabetes in work } \\
\text { place }\end{array}$ & Never & Rarely & Sometimes & Often \\
\hline Difficulty in performing duties & 15 & 66 & 17.5 & 1.5 \\
\hline $\begin{array}{l}\text { Difficulty in controlling } \\
\text { emotions with co-workers }\end{array}$ & 21 & 37 & 30 & 12 \\
\hline $\begin{array}{l}\text { Feel less productive at work } \\
\text { than needed }\end{array}$ & 16 & 49 & 31 & 4.5 \\
\hline Absenteeism from work & 15 & 46 & 33 & 5 \\
\hline $\begin{array}{l}\text { Reschedule meetings, arrive } \\
\text { late, or leave early from work }\end{array}$ & 15 & 55 & 24 & 6.5 \\
\hline
\end{tabular}

Table 4: Impact of Diabetes on reaching goals

\begin{tabular}{lcccc}
\hline $\begin{array}{l}\text { Impact of diabetes } \\
\text { on reaching goals }\end{array}$ & Not at all & Slightly Somewhat & Very \\
\hline $\begin{array}{l}\text { Prevents from achieving } \\
\text { short-term goals }\end{array}$ & 50 & 45 & 5 & - \\
$\begin{array}{l}\text { Prevents from achieving } \\
\text { long-term goals }\end{array}$ & 24 & 44 & 30 & 2 \\
\hline
\end{tabular}

systemic complications. Thus, prevention, delaying the complications, and effective treatment of complications in diabetes is crucial to improve the social and economic enormities of the disease.

\section{CONCLUSION}

Diabetes is a progressive condition and one should never be complacent that it is a "mild" form of disease. The objective of treatment should be to achieve and maintain long-term near-normal blood glucose, lipid, and blood pressure levels. It is also recognized that adoption of self-management skills is necessary to enable them to manage their disease well.

The figures in the 2015 IDF Diabetes Atlas demonstrate India, the country with the second highest number of people living with diabetes, spent $<3 \%$ of the global total (ID23 billion) expenditure on diabetes. To meet the 2025 target of no increase in diabetes, much more needs to be done. Whole population must change their lifestyle behaviors by modifying diet and increasing physical activity levels. ${ }^{[10]}$

Financial support and sponsorship

Nil.

Conflicts of interest

There are no conflicts of interest.

\section{REFERENCES}

1. Zimmet P, Alberti KG, Shaw J. Global and societal implications of the diabetes epidemic. Nature 2001;414:782-7.

2. Patterson CC, Dahlquist GG, Gyürüs E, Green A, Soltész G; Eurodiab Study Group. Incidence trends for childhood type 1 
diabetes in Europe during 1989-2003 and predicted new cases 2005-20: A multicentre prospective registration study. Lancet 2009;373:2027-33.

3. Ramachandran A, Snehalatha C, Yamuna A, Mary S, Ping Z. Cost-effectiveness of the interventions in the primary prevention of diabetes among Asian Indians: Within-trial results of the Indian diabetes prevention programme (IDPP). Diabetes Care 2007;30:2548-52.

4. Bastida E, Pagán JA. The impact of diabetes on adult employment and earnings of Mexican Americans: Findings from a community based study. Health Econ 2002;11:403-13.

5. Vijan S, Hayward RA, Langa KM. The impact of diabetes on workforce participation: Results from a national household sample. Health Serv Res 2004;39(6 Pt 1):1653-69.
6. United Nations. Report of the United Nations Conference on Sustainable Development. Rio de Janeiro, Brazil: United Nations; 2012.

7. Satman I, Akalin S, Ozdemir O. Impairment of work productivity and daily activities in Turkish patients with type 2 diabetes mellitus. Value Health 2012;15:A277-575.

8. Lavigne JE, Phelps CE, Mushlin A, Lednar WM. Reductions in individual work productivity associated with type 2 diabetes mellitus. Pharmacoeconomics 2003;21:1123-34.

9. Korff M, Katon W, Elizabeth H, Gregory S, Ciechanowski P. Work disability among individuals with diabetes. Diabetes Care 2005;28:1326-32.

10. International Diabetes Federation. Diabetes Atlas. $7^{\text {th }}$ ed. Brussels, Belgium: International Diabetes Federation; 2015. 